\title{
Russia as a Subject of the World Market for Staple Tropical Fruits
}

\author{
Rafail R. Mukhametzyanov $\left.{ }^{1 *[O R C I D} 0000-0002-1239-5201\right]$, \\ Anastasiya S. Zaretskaya 2[ORCID 0000-0002-8438-7729], \\ Gulnara K. Dzhancharova 1[ORCID 0000-0002-1098-7430], \\ Nikolay G. Platonovskiy 1[ORCID 0000-0002-9189-8340], \\ Natalya N. Ivantsova 1[ORCID 0000-0001-8478-1067]
}

\author{
${ }^{1}$ Russian State Agrarian University - Moscow Timiryazev Agricultural Academy, Moscow, Russia \\ ${ }^{2}$ Yaroslav-the-Wise Novgorod State University, Veliky Novgorod, Russia \\ mrafailr@yandex.ru
}

\begin{abstract}
The production of tropical fruits and their supply to the world market is one of the spheres of employment for a significant part of the citizens of developing countries, a source of income for their families and foreign exchange earnings for the countries concerned. At the same time, for the countries that import them, they are currently an important element in meeting the needs of their population in fruit and berry products in terms of volumes, assortment and availability throughout the entire calendar year. The main tropical fruits are bananas, pineapples, avocados, mangoes, papaya. Considering that the Food and Agriculture Organization of the United Nations has declared 2021 the International Year of Fruits and Vegetables, the problem of identifying the importance of Russia as a subject of the world market for these types of fruit and berry products is of great importance. Within the framework of this study, statistics from the Food and Agriculture Organization of the United Nations were used, on the basis of which for 1992-2019 changes in global production, global and Russian imports of major tropical fruits were analyzed. The shares of global imports in the global production of the types of fruit and berry products under consideration, the importance of Russia in their global physical and value imports were also calculated and characterized. In more detail, according to the official data of customs statistics, for 2020, the directions and volumes of imports to Russia and exports from Russia of the main types of tropical fruits are reflected. In the course of the study, it was revealed that in 1992-2019 the volumes of global production and international trade in these types of fruit and berry products increased, and the importance of Russia as their importer has significantly increased. The share of global imports of major tropical fruits in their global production also increased. As for the import of these types of fruit and berry products to Russia, there is a high concentration of one to three countries from which the tropical fruits come.
\end{abstract}

Keywords: Russia, world market of tropical fruits, international trade, import, export

\section{INTRODUCTION}

In the modern economy, especially in the developed countries of the world, human labor is increasingly acquiring an intellectual character, and hard physical labor is becoming a thing of the past. To replenish the energy and nutrients expended in the process of mental activity, increased use of food saturated with vitamins, organic acids, macro- and microelements of food is required. Fresh fruits and vegetables are a valuable source of most of them. Moreover, many fruits, berries, nuts, vegetables and melons contain antioxidants, which increases the importance of their consumption $[1,2]$.

This is confirmed by research by scientists specializing in the field of dietetics and healthy eating [3]. In their scientific works, they constantly state facts proving that regular consumption of fresh fruits, berries and nuts not only positively affects the 
work of the digestive, cardiovascular, excretory, nervous and other systems of the human body, but also prevents the development of incurable diseases [4]. In some scientific works, the authors study the impact of consumption of fruits and vegetables on reducing the risk of depression and note the positive effect of their presence in the diet, including adolescents $[5,6]$. Considering the above, we hold the view that the provision of the population with fruit and berry and vegetable products in accordance with the norms of rational nutrition recommended by official medical organizations of the international and national levels, largely determines the health and longevity of both the individual and the prosperity of the society of a particular state in general. Like other types of fruit and berry products, tropical fruits contain substances useful for the body, which is confirmed by the studies of domestic and foreign scientists [7]. Some of them, in their scientific works, pay more attention to the impact of consumption on human health of specific ones, for example, bananas [8] or avocados [9].

The production of fruits, berries and nuts, including in the equatorial, subequatorial and tropical climatic zones, is carried out in the horticultural industries [10]. They are cultivated by large agricultural organizations and farms in order to profit from supplies to national and international markets. Whereas the rural population grows them mainly to meet their own needs [11]. Some of the tropical fruits such as bananas and pineapples have been export-import targets for a long time. Gradually, due to the increased scale of the generated mass of these fruits and their international transportation, the cost of their unit, especially in conditions of competition on the global and national markets, including in comparison with substitute goods, has relatively decreased. This led to the fact that they became more physically and economically accessible for the population of the developed countries of Europe and North America already in the $1970 \mathrm{~s}-80 \mathrm{~s}$, which at that time the majority of the inhabitants of the USSR could not afford. At that time, the state policy of the authorities was aimed at achieving maximum satisfaction of the need for agricultural raw materials and food, including fruit and vegetable products, at the expense of their own production.

Moreover, at that time the country included the republics of Central Asia and Transcaucasia, Ukraine, Moldova, i.e. territories with more favorable conditions than in Russia for the cultivation of fruit and berry crops. Nevertheless, some fruits, berries and nuts were purchased in insignificant volumes abroad, but for the most part they were physically and economically accessible only to a small part of the inhabitants of the USSR, first of all, megalopolises and large cities [12]. In particular, in the 1960s-70s and especially in the 1980s separate tropical (bananas and pineapples) and subtropical (oranges, lemons, tangerines) fruits were supplied to the USSR [13]. However, their share in the total consumption of fruit and berry products by the population was insignificant.

The collapse of the USSR led to the destruction of the single economic space, the rupture of many previously created economic ties, including in the fruit and vegetable subcomplex [14]. The commercial structures that emerged in the early 1990s and the authorities responsible for the food supply of megalopolises and large cities of the European part of Russia began to increase the purchases of fruit and berry products in non-CIS countries [15]. However, tropical fruits (except for bananas) were still a "luxury item" for an average Russian consumer.

The growth of the Russian economy and population incomes in the first decade of the $21 \mathrm{st}$ century led to an increase in imports of fruits, berries and nuts. As a result, Russia has become one of the states that are the main importers of the fruit and berry production, occupying leading positions in the import of many of them [16]. In particular, in 2011, Russia was in first place in the world in terms of physical imports of apples, tangerines, oranges, pears, cherries, plums, apricots, and prunes; second place for grapes, peaches and nectarines, lemons and limes, dried apricots, peeled walnuts; the third - for bananas, grapefruits; the fourth - for peeled peanuts, kiwis, peeled hazelnuts [17]. Given the increased purchasing power of the population, in addition to bananas, the supply of other staple tropical fruits, which also include pineapples, avocados, mangoes and papayas, also increased [18]. Moreover, their maximum physical and value volumes fell on the second decade of the 21 st century. In this regard, the stated problem of research on identifying the importance of Russia as a subject of the world market for staple tropical fruits is of particular relevance

\section{MATERIALS AND METHODS}

The aim of the study is to identify changes in the development of the world market for staple tropical fruits in 1992-2019 in the context of defining the meaning of Russia as its subject. To achieve this aim, the following tasks were identified: 
- to analyze the dynamics of global production, global and Russian imports of the designated types of fruit and berry products during the covered time of the study;

- to characterize for 1992-2019 the changes in the share of global imports in the global production of staple tropical fruits, the share of Russia in global physical and value imports;

- to consider in more detail the directions and volumes of imports to Russia and exports from Russia of the main types of tropical fruits.

The main information base for the research was the statistical data of the FAO (Food and Agriculture Organization of the United Nations). Their analysis was carried out using the following method: within the general period of dynamics from 1992 to 2019 , three sub-periods were identified: 1992-2000, 20012010, 2011-2019. The average annual values for each of them were calculated, and the situation in 2019 was compared with respect to 1992 .

Also, for a more detailed examination of the situation in 2020 for the main countries acting as exporters to Russia and importers of the staple tropical fruits from Russia, data from the customs statistics of the Russian Federation, grouped at http://customsonline.ru. were used. The volumes and structure of physical and value imports and exports of the considered types of fruit and berry products are analyzed.

\section{RESULTS}

Let us describe in more detail the results of the analysis carried out in the framework of the study of the problem of identifying the importance of Russia as a subject of the world market for the staple tropical fruits. Let us consider the change in the global production of these types of fruit and berry products, their global and Russian imports for 19922019 (Table 1).

The most significant tropical fruit is the banana. Whereas in 1992 its gross collections amounted to 55.613 million tons, then in $2019-116.782$ million tons, i.e. increased by 2.1 times. The second and third places in 2019 were held by mangoes and pineapples. Their global production volumes increased by 3.02 times and by 2.29 times as compared to 1992 , respectively. The largest gains during the period covered by us were observed for papaya (by 3.18 times) and avocado (by 3.35 times).
However, the volumes of global and Russian imports in the main tropical fruits (excluding bananas) for 1992-2019 grew at a more significant pace.

So, in the world as a whole, for avocados they increased by 14.02 times, for mangoes - by 8.13 times, for papayas - by 6.22 times, for pineapples by 5.72 times. Some foreign authors believe that tropical fruits, in particular, avocados, still have growth potential, both in terms of production volumes and its supply to international trade [19].

Table 1. Change in global production, world and Russian imports of staple tropical fruits for 19922019

\begin{tabular}{|c|c|c|c|c|c|c|}
\hline \multirow[b]{2}{*}{$\begin{array}{c}\text { Type of } \\
\text { Fruit }\end{array}$} & \multirow[b]{2}{*}{ 응 } & \multicolumn{3}{|c|}{ Average for the year } & \multirow[b]{2}{*}{$\frac{\text { ำ }}{\text { నิ }}$} & \multirow{2}{*}{\begin{tabular}{|c} 
Relative \\
Growth \\
2019 to \\
1992 , by \\
... times
\end{tabular}} \\
\hline & & 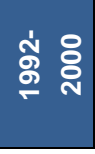 & 홍 융 & 둥 웅 & & \\
\hline \multicolumn{7}{|c|}{ Global production volumes, million tons } \\
\hline avocado & 2.14 & 2.26 & 3.33 & 5.46 & 7.18 & \\
\hline bananas & 55.61 & 61.29 & 87.37 & 112.17 & 116.78 & 10 \\
\hline mango & 3.51 & 22.41 & 32.26 & 47.63 & 55.85 & .02 \\
\hline papa & 1 & 91 & 24 & 12.60 & 73 & \\
\hline oir & 2.31 & 13.42 & 18.32 & 25.88 & 28.18 & 9 \\
\hline \multicolumn{7}{|c|}{ Worldwide imports, million tons } \\
\hline avoc & 19 & 0.24 & 0.63 & 1.78 & 2.65 & 02 \\
\hline bana & 10.67 & 12.89 & 15.91 & 20.59 & $2 c .00$ & \\
\hline mang & 0.22 & 0.41 & 0.82 & 1.43 & 1.78 & 3.13 \\
\hline papaya & 06 & 0.11 & 0.24 & 0.32 & 36 & 22 \\
\hline pineapple & 0.63 & 0.81 & 2.03 & 3.21 & 3.61 & 5.72 \\
\hline \multicolumn{7}{|c|}{ Volumes of Russian imports, thousand tons } \\
\hline avoc & 0.0 & 0.3 & 3.3 & 17.5 & 35.6 & - \\
\hline bananas & 13.1 & 360.6 & 871.4 & 1375.1 & 1512.4 & 115.45 \\
\hline mango & & 0.0 & 0.1 & 12.7 & 31.1 & - \\
\hline papaya & 0 & 0.0 & 0.2 & 0.4 & 0.6 & - \\
\hline pineappl & 0.9 & 7.0 & 28.1 & 45.3 & 51.1 & 60.17 \\
\hline
\end{tabular}

Source: Compiled and calculated by the authors based on FAO data

Let us calculate and characterize the change in the share of global imports in the global production of major tropical fruits, as well as in the share of Russia in global physical and value imports for 1992-2019 (Table 2).

It is noticeable that according to the first of these criteria, the situation has changed significantly during the time covered by us. Thus, in 1992, the share of world imports of avocados in the global production of this fruit was $8.81 \%$, while that of bananas was $19.18 \%$. However, in 2019 , the calculated figure for avocado was $36.86 \%$, i.e. it 
increased by $28.05 \%$. At the same time, the growth for bananas was only $0.51 \%$. Pineapples are in third place in this indicator. In 2019, their level was $12.82 \%$, while in $1992-5.13 \%$. The bulk of mango and papaya is consumed in the countries where they are grown. As for Russia, its share in global physical and value imports in 1992-2019 increased significantly.

Table 2. Change in the share of global imports in global production of staple tropical fruits, the share of Russia in global physical and value imports for 1992-2019, \%

\begin{tabular}{|c|c|c|c|c|c|c|}
\hline \multirow[b]{2}{*}{$\begin{array}{c}\text { Type of } \\
\text { Fruit }\end{array}$} & \multirow[b]{2}{*}{ \% } & \multicolumn{3}{|c|}{ Average for the year } & \multirow[b]{2}{*}{ ㅇํํ } & \multirow{2}{*}{\begin{tabular}{|c} 
Absolute \\
Growth \\
2019 to \\
1992 \\
\end{tabular}} \\
\hline & & จั่ จั & 홍 웅 & 둥 & & \\
\hline \multicolumn{7}{|c|}{ Share of global imports in global production } \\
\hline avocado & 8.81 & 10.68 & 18.84 & 32.65 & 36.86 & 28.05 \\
\hline bananas & 19.18 & 21.03 & 18.22 & 18.35 & 19.69 & 0.51 \\
\hline mango & 1.18 & 1.81 & 2.55 & 3.01 & 3.18 & 2.00 \\
\hline papaya & 1.33 & 1.79 & 2.63 & 2.52 & 2.59 & 1.27 \\
\hline pineapple & 5.13 & 6.03 & 11.10 & 12.42 & 12.82 & 7.68 \\
\hline \multicolumn{7}{|c|}{ Russia's share in global physical imports } \\
\hline avocado & 0.00 & 0.14 & 0.53 & 0.98 & 1.35 & 1.34 \\
\hline bananas & 0.12 & 2.80 & 5.48 & 6.68 & 6.58 & 6.46 \\
\hline mango & 0.00 & 0.00 & 0.38 & 0.89 & 1.75 & 1.75 \\
\hline papaya & 0.00 & 0.01 & 0.07 & 0.14 & 0.16 & 0.16 \\
\hline pineapple & 0.13 & 0.86 & 1.38 & 1.41 & 1.42 & 1.28 \\
\hline \multicolumn{7}{|c|}{ Russia's share in global value imports } \\
\hline avocado & 0.01 & 0.06 & 0.26 & 0.79 & 1.26 & 1.25 \\
\hline bananas & 0.10 & 2.24 & 5.06 & 7.21 & 7.29 & 7.18 \\
\hline mango & 0.00 & 0.00 & 0.44 & 1.27 & 2.67 & 2.67 \\
\hline papaya & 0.00 & 0.01 & 0.10 & 0.29 & 0.54 & 0.54 \\
\hline pineapple & 0.14 & 0.81 & 1.22 & 2.02 & 2.03 & 1.88 \\
\hline
\end{tabular}

Source: Compiled and calculated by the authors based on FAO data

Based on the data of domestic customs statistics for 2020, we will reflect in more detail the main supplying countries of the staple tropical fruits to Russia, and the corresponding volumes of their physical and value imports (Table 3).

The leader in terms of import of bananas is Ecuador: this country accounted for $96.31 \%$ of the 1.516 million tons of this fruit supplied to Russia. For pineapples, the situation is almost the same, only Costa Rica is in the first position, which supplied $90.75 \%$ of 53.306 thousand tons of imports of this fruit to Russia. For avocados and mangoes, there is no such concentration of receipts from one country, but the five main countries account for $91.98 \%$ and $89.83 \%$, respectively. As for papaya, $94.67 \%$ of the physical import of this fruit to Russia is taken by two countries: Brazil (50.12\%) and Thailand $(44.55 \%)$.

Table 3. Countries, volumes and structure of imports of the main types of tropical fruits to Russia in 2020

\begin{tabular}{|c|c|c|c|c|}
\hline \multirow[b]{2}{*}{ Country } & \multicolumn{2}{|c|}{ Physical Imports } & \multicolumn{2}{|c|}{ Value Imports } \\
\hline & tons & $\%$ & $\begin{array}{c}\text { thousand } \\
\text { dollars }\end{array}$ & $\%$ \\
\hline \multicolumn{5}{|c|}{ bananas } \\
\hline Ecuador & 1459849.7 & 96.31 & 1072436.5 & 96.05 \\
\hline Guatemala & 20174.8 & 1.33 & 14743.0 & 1.32 \\
\hline Costa Rica & 17308.9 & 1.14 & 12670.9 & 1.13 \\
\hline Colombia & 15130.5 & 1.00 & 11009.7 & 0.99 \\
\hline Vietnam & 1913.6 & 0.13 & 4547.2 & 0.41 \\
\hline Other countries & 1339.9 & 0.09 & 1171.3 & 0.10 \\
\hline In total & 1515717.4 & 100.0 & 1116578.6 & 100.0 \\
\hline \multicolumn{5}{|c|}{ pineapple } \\
\hline Costa Rica & 48374.3 & 90.75 & 47668.6 & 88.53 \\
\hline China & 1716.0 & 3.22 & 2080.1 & 3.86 \\
\hline Ecuador & 1240.3 & 2.33 & 1153.6 & 2.14 \\
\hline Panama & 785.8 & 1.47 & 873.4 & 1.62 \\
\hline Philippines & 624.0 & 1.17 & 686.0 & 1.27 \\
\hline Other co & 565.3 & 1.06 & 1380.4 & 2.56 \\
\hline In total & 53305.6 & 100.0 & 53842.0 & 100.0 \\
\hline \multicolumn{5}{|c|}{ avocado } \\
\hline Peru & 14481.9 & 30.56 & 3003 & 24.67 \\
\hline Israel & 14275.2 & 30.12 & 45652.9 & 37.50 \\
\hline Kenya & 6442.7 & 13.59 & 14251.5 & 11.71 \\
\hline Colombia & 4776.4 & 10.08 & 13263.4 & 10.90 \\
\hline South Africa & 3618.2 & 7.63 & 8537.5 & 7.01 \\
\hline Other countries & 3797.0 & 8.01 & 9988.5 & 8.21 \\
\hline In total & 47391.3 & 100.0 & 121725.7 & 100,0 \\
\hline \multicolumn{5}{|c|}{ mango } \\
\hline Peru & 11767.7 & 30.41 & 22826.2 & 27.33 \\
\hline Brazil & 8978.9 & 23.20 & 17257.4 & 20.67 \\
\hline China & 5746.4 & 14.85 & 11725.6 & 14.04 \\
\hline Egypt & 5245.7 & 13.56 & 9874.0 & 11.82 \\
\hline Vietnam & 3020.4 & 7.81 & 11075.2 & 13.26 \\
\hline Other cour & 3936.1 & 10.17 & 10749.6 & 12.87 \\
\hline In total & 38695.2 & 100.0 & 83508.0 & 100.0 \\
\hline \multicolumn{5}{|c|}{ papaya } \\
\hline Brazil & 224.6 & 50.12 & 767.0 & 36.45 \\
\hline Thailand & 199.6 & 44.55 & 1239.9 & 58.93 \\
\hline Vietnam & 11.7 & 2.61 & 67.3 & 3.20 \\
\hline Philippines & 5.0 & 1.10 & 6.4 & 0.31 \\
\hline Belarus & 2.6 & 0.58 & 1.2 & 0.05 \\
\hline Other countries & 4.6 & 1.03 & 22.3 & 1.06 \\
\hline In total & 448.1 & 100.0 & 2104.2 & 100.0 \\
\hline
\end{tabular}

Source: Compiled and calculated by the authors based on the customs statistics of the Russian Federation 
Let us consider the countries, volumes and structure of exports from Russia of the staple types of tropical fruits in 2020 (Table 4).

Table 4. Countries, volumes and structure of exports from Russia of the main types of tropical fruits in 2020

\begin{tabular}{|c|c|c|c|c|}
\hline \multirow[b]{2}{*}{ Country } & \multicolumn{2}{|c|}{ Physical Imports } & \multicolumn{2}{|c|}{ Value Imports } \\
\hline & tons & $\%$ & $\begin{array}{l}\text { thousand } \\
\text { dollars }\end{array}$ & $\%$ \\
\hline \multicolumn{5}{|c|}{ bananas } \\
\hline Kazakhstan & 33018.4 & 51.35 & 21008.9 & 52.86 \\
\hline Belarus & 24190.6 & 37.62 & 14760.5 & 37.14 \\
\hline Ukraine & 3928.1 & 6.11 & 2087.3 & 5.25 \\
\hline Kyrgyzstan & 1791.2 & 2.79 & 1131.1 & 2.85 \\
\hline Uzbekistan & 644.2 & 1.00 & 331.9 & 0.84 \\
\hline Other countries & 722.9 & 1.12 & 426.2 & 1.07 \\
\hline In total & 64295.4 & 100.0 & 39746.0 & 100.0 \\
\hline \multicolumn{5}{|c|}{ pineapple } \\
\hline Ukraine & 192.4 & 27.91 & 156.7 & 30.07 \\
\hline Belarus & 157.8 & 22.90 & 101.0 & 19.38 \\
\hline Kazakhstan & 152.8 & 22.17 & 147.9 & 28.38 \\
\hline Tajikistan & 88.7 & 12.87 & 41.5 & 7.97 \\
\hline Uzbekistan & 61.3 & 8.90 & 42.4 & 8.14 \\
\hline Other countries & 36.2 & 5.26 & 31.6 & 6.06 \\
\hline In total & 689.2 & 100.0 & 521.2 & 100.0 \\
\hline \multicolumn{5}{|c|}{ avocado } \\
\hline Ukraine & 85.1 & 54.31 & 131.6 & 41.23 \\
\hline Kazakhstan & 31.8 & 20.33 & 126.6 & 39.69 \\
\hline Uzbekistan & 25.0 & 15.96 & 15.4 & 4.83 \\
\hline Kyrgyzstan & 12.4 & 7.93 & 42.4 & 13.28 \\
\hline South Ossetia & 1.3 & 0.83 & 0.0 & 0.01 \\
\hline Other countries & 1.0 & 0.63 & 3.0 & 0.95 \\
\hline In total & 156.7 & 100.0 & 319.1 & 100.0 \\
\hline \multicolumn{5}{|c|}{ mango } \\
\hline Ukraine & 96.6 & 69.69 & 355.7 & 80.63 \\
\hline Belarus & 20.4 & 14.74 & 24.3 & 5.51 \\
\hline Uzbekistan & 8.3 & 5.96 & 7.3 & 1.65 \\
\hline Kazakhstan & 4.3 & 3.07 & 24.7 & 5.60 \\
\hline Turkmenistan & 3.2 & 2.29 & 1.5 & 0.34 \\
\hline Other countries & 5.9 & 4.25 & 27.7 & 6.27 \\
\hline In total & 138.6 & 100.0 & 441.2 & 100.0 \\
\hline \multicolumn{5}{|c|}{ papaya } \\
\hline Belarus & 0.055 & 60.38 & 0.459 & 56.83 \\
\hline Kazakhstan & 0.024 & 26.55 & 0.202 & 25.04 \\
\hline Ukraine & 0.012 & 13.07 & 0.147 & 18.13 \\
\hline In total & 0.092 & 100.0 & 0.808 & 100.0 \\
\hline
\end{tabular}

Source: Compiled and calculated by the authors based on the customs statistics of the Russian Federation

As one can see, in almost all of them the leading positions are occupied by Kazakhstan, Belarus, Ukraine, as well as Uzbekistan. So, in 2020, 51.35\% of bananas, $22.17 \%$ of pineapples, $20.33 \%$ of avocados, $3.07 \%$ of mangoes and $26.55 \%$ of papayas were supplied to Kazakhstan from the total volume of export of the staple tropical fruits from Russia. The export parameters of these fruits from Russia to Belarus amounted to $37.62 \%, 22.9 \%$, $0.45 \%, 14.74 \%$ and $60.38 \%$, respectively. As for Ukraine, in 2020 from the territory of Russia $6.11 \%$ of bananas, $29.91 \%$ of pineapples, $54.31 \%$ of avocados, $69.69 \%$ of mangoes and $13.07 \%$ of papayas from the total volume of their exports from Russia were imported to this state.

\section{DISCUSSION}

The efficiency of production and marketing of fruit and berry products depends on many factors, among which natural and climatic conditions are of decisive importance [20]. Most types of fruits, berries and nuts are heat-loving crops, which determines the high degree of dependence of their cultivation on the temperature and light conditions of the environment. That is why the production of fruit and berry products from the group under consideration is carried out in the equatorial, subequatorial and tropical climatic zones of the Earth.

As our studies show, in recent decades, Latin American countries have been one of the main producers and suppliers of tropical fruits to the world market [21]. For example, for bananas it was Ecuador (1st place), Guatemala (2nd place), Costa Rica (4th place), Colombia (5th place). Costa Rica (1st place), Ecuador (4th place) and Honduras (5th place) are in the top five producing countries for supplies to the international pineapple trade, for avocado supplies - Mexico, Peru and Chile, and for mango - Mexico, Brazil and Peru [22]. The main exporters of papaya are Mexico, Guatemala and Brazil [23]. At the same time, one of the main foreign markets for tropical fruits from Latin America is the United States [24], as well as the European Union and Russia.

The production and export of these types of fruit and berry products, in addition to solving their own food problem, contributes to employment and is a source of income for a certain part of the population of developing countries in this region of the world. In addition, the supply of tropical fruits to international trade leads to the flow of foreign exchange earnings to these countries. And this is important from the point of view of ensuring the stability of the national currency and the state of the balance of payments [25]. 
It may seem to the modern consumer of fruit and berry products that the world market for tropical fruits is characterized by the greatest liberalization, since they are not produced in the developed countries of the world (with the exception of the USA). Therefore, there is no need for them to somehow restrict their international trade. However, in the relatively recent past, there were similar examples.

In particular, in the mid-1970s The European Economic Community granted a duty-free banana trade to the former colonies of European powers, while the supply of this fruit from Latin America was subject to quotas and import duties [26]. It took several decades to solve this problem. Other problems arise, including of a geopolitical nature, which also have an impact on restrictions on international trade in tropical fruits.

Nevertheless, despite these cases, over the past six decades, not only the global gross harvests of fruits, berries and nuts, including tropical ones, but also the parameters of international trade in them have increased significantly [27]. Undoubtedly, this is the advantage of globalization and foreign economic liberalization, when due to the increased specialization and concentration of the horticultural industries we are considering in specific countries, characterized by the most favorable conditions for growing these types of products, there is an increase in both their production volumes and export-import operations with them.

Considering that the FAO has declared 2021 the International Year of Fruits and Vegetables, the research problem we have declared is significantly actualized [28], especially for those countries where tropical fruits are grown both to provide their own population with food and to develop the export potential of the relevant industries. In a number of developing countries, for example, in Indonesia, there are special research institutes studying these types of fruit and berry products and developing technologies to increase their competitiveness in the world market [29]. Some scientists are working on the study of supplies to the developed countries of the world processed from tropical fruits, such as bananas, food products [30]. Also, foreign experts, in order to more effectively use the potential of these types of fruit and berry products, are studying technologies associated with the extraction of bioactive compounds useful for human health from the waste of tropical fruits processing [31].

The analysis of the literature indicates that one of the main problems regarding the further development of the production of basic tropical fruits in specific countries, and, accordingly, the directions and volumes of international trade in them, is climate change [32]. It is also a matter of concern that the development of this industry, including for the cultivation of the types of fruit and berry products we are considering for export, is associated with an increase in the area for plantations of tropical fruits. And for the negative impact on the prospects for the conservation of biodiversity of flora and fauna in the respective states [33], which for the most part are developing.

As for Russia, it will continue to act on the world market for tropical fruits as a subject of demand for them, since its natural and climatic conditions do not allow them to be produced, especially on an industrial scale.

\section{CONCLUSION}

On the basis of the study carried out to identify the importance of Russia as a subject of the world market for the main tropical fruits, we consider it expedient to draw the following conclusions, which may become the basis for further discussion of this problem.

First, during the time covered by the study, the volumes of global production and international trade of the types of fruit and berry products under consideration increased. In particular, gross harvests of major tropical fruits in aggregate rose from 92.884 million tonnes in 1992 to 221.729 million tonnes in 2019 , i.e. by 2.39 times. At the same time, the rate of change in export-import transactions with them was more significant. In particular, if in 1992 their total global imports amounted to 11.762 million tons, then in $2019-31.385$ million tons, i.e. increased by 2.67 times. As a result, the share of global imports of major tropical fruits in their global production for $1992-2019$ increased from $12.66 \%$ to $14.15 \%$.

Secondly, Russia acts on the world tropical fruit market mainly as a subject of demand. Moreover, for 1992-2019 the importance of Russia in international trade in these types of fruit and berry products from the point of view of their import has grown significantly. Whereas in 1992-2000 its share was only $0.12 \%$ in physical and $0.1 \%$ in value terms, then in $2011-2019-5.31 \%$ and $4.84 \%$, respectively. In 2019, in the global ranking in terms of physical imports, Russia ranked third in bananas, ninth in avocados, thirteenth in mangoes, fourteenth in pineapples, and eighty-eighth in papayas [34]. 
Thirdly, Russia in 1992-2019 increased the volume of foreign trade in basic tropical fruits not only in terms of their import to Russia, but also their export through re-export to some neighboring states, such as Kazakhstan, Belarus, Ukraine, Uzbekistan, Kyrgyzstan, Turkmenistan, Mongolia, Armenia. However, they are not so significant in relation to their import to Russia. In 2020, the export of bananas from Russia amounted to $4.24 \%$ of the volume of their import, pineapples - $1.29 \%$, avocados $-0.33 \%$, mangoes $-0.36 \%$ and papayas only $0.02 \%$.

\section{AUTHORS' CONTRIBUTIONS}

The contribution to this study from each of the authors is: Rafail R. Mukhametzyanov - 0.6, Anastasiya S. Zaretskaya - 0.1, Gulnara K. Dzhancharova - 0.1, Nikolay G. Platonovskiy - 0.1, Natalya N. Ivantsova -0.1

\section{REFERENCES}

[1] M. del Rio-Celestino, R. Font, "The Health Benefits of Fruits and Vegetables", Foods, 2021, vol. 9(3), p. 369. DOI: 10.3390/foods 9030369

[2] R. Dhalaria, R. Verma, D. Kumar, S. Puri, A. Tapwal, V. Kumar, E. Nepovimova, K. Kuca, "Bioactive Compounds of Edible Fruits with Their Anti-Aging Properties: A Comprehensive Review to Prolong Human Life", Antioxidants, 2020, vol. 9(11), p. 1123. DOI: $10.3390 /$ antiox 9111123

[3] T.C. Wallace, R. L. Bailey, J.B. Blumberg, B. Burton-Freeman, C.Y.O. Chen, K.M. CroweWhite, A. Drewnowski, S. Hooshmand, E. Johnson, R. Lewis, R. Murray, S.A. Shapses, D.D. Wang, "Fruits, vegetables, and health: A comprehensive narrative, umbrella review of the science and recommendations for enhanced public policy to improve intake", Critical Reviews in Food Science and Nutrition, 2020, vol. 60(13), pp. 2174-2211. DOI: 10.1080/10408398.2019.1632258

[4] M.L. Dreher, "Whole Fruits and Fruit Fiber Emerging Health Effects", Nutrients, 2018, vol. 10(12), p. 1833. DOI: 10.3390/nu10121833

[5] E. Hoare, M. Hockey, A. Ruusunen, F.N. Jacka, "Does Fruit and Vegetable Consumption During Adolescence Predict Adult Depression? A Longitudinal Study of US Adolescents", Frontiers in Psychiatry, 2018, vol. 9, p. 581.

\section{DOI: $10.3389 /$ fpsyt.2018.00581}

[6] P.Y. Huang, M. O'Keeffe, C. Elia, A. Karamanos, L.M. Goff, M. Maynard, J.K. Cruickshank, S. Harding, "Fruit and vegetable consumption and mental health across adolescence: evidence from a diverse urban British cohort study", International Journal of Behavioral Nutrition and Physical Activity, 2019, vol. 16(19), p. 19. DOI: 10.1186/s12966019-0780-y

[7] S. Sayago-Ayerdi, D.L. Garcia-Martinez, A.C. Ramirez-Castillo, H.R. RamirezConcepcion, M. Viuda-Martos, "Tropical Fruits and Their Co-Products as Bioactive Compounds and Their Health Effects: A Review", Foods, 2021, vol. 10(8), p. 1952. DOI: 10.3390/foods 10081952

[8] J.S. Sidhu, T.A. Zafar, "Bioactive compounds in banana fruits and their health benefits", Food Quality and Safety, 2018, vol. 2(4), pp. 183188. DOI: $10.1093 /$ fqsafe/fyy019

[9] A.S. Vivero, R.B. Valenzuela, A.B. Valenzuela, G.M. Morales, "Bioactive Compounds and Potential Health Benefits of Avocado", RevistaChilena de Nutricion, 2021, vol. 46(4), pp. 491-498. DOI: 10.4067/S071775182019000400491

[10] "Agricultural economics: Textbook for academic bachelor's degree" ["Ekonomika sel'skogo hozyajstva: uchebnik dlya akademicheskogo bakalavriata"], in Ed. by N.Y. Kovalenko, Moscow, Urait, 2019, 406 p. (In Russ.).

[11] Y.I. Agirbov, R.R. Mukhametzyanov, E.V. Britik, "Russia in the world production and market of potatoes and fruit and vegetable products", Economy of Agricultural and Processing Enterprises, 2020, vol. 9, pp. 74-83. (In Russ.). DOI: 10.31442/0235-2494-2020-0-974-83

[12]Y.I. Agirbov, R.R. Mukhametzyanov, D.V. Storozhev, "Current state and trends of export and import of fruits and vegetables in the world", Economy of Agricultural and Processing Enterprises, 2019, vol. 6, pp. 56-63. (In Russ.). DOI: 10.31442/0235-2494-2019-0-656-63

[13] Y.I. Agirbov, R.R. Mukhametzyanov, "Russia is in the international trade in citrus fruits", Economics of Agriculture of Russia, 2020, vol. 7, pp. 103-110. (In Russ.). DOI: 10.32651/207-193 
[14]Y.I. Agirbov, S.S. Voloshchenko, R.R. Mukhametzyanov, I. Semenov, "Current state and main directions of development of the regional fruit and vegetable complex in Russia" [Sovremennoe sostoyaniye i osnovnye napravleniya razvitiya regional'nogo plodoovoshchnogo podkompleksa Rossii], International Agricultural Journal, 1998, vol. 1, pp. 52-55. (In Russ.)

[15] N.Y. Kovalenko, G.Z. Ibiev, "Ways to solve the problem of providing the Moscow region with fruit and berry products of domestic production", Economy of Agricultural and Processing Enterprises, 2018, vol. 11, pp. 36-38. (In Russ.).

[16]R.R. Mukhametzyanov, Y.I. Agirbov, A.S. Zaretskaya, G.Z. Ibiev, D.V Storozhev, "Development trends of the Russian fruit and berry market, Advances in Economics", in Proceedings of ISPC «Russia 2020 - a new reality: economy and society», Advances in Economics, Business and Management Research, 2021, vol. 164, pp. 287-292.

[17]Z.V. Udalova, R.R. Mukhametzyanov, "Development dynamics of modern fruit and vegetable market in Russia", The Russian Customs Academy Messenger, 2015, vol. 3, pp. 36-45. (In Russ.).

[18] Y.I. Agirbov, R.R. Mukhametzyanov, "Trends of import of fruit and berry products in the world and to the Russian Federation", Economics of Agriculture of Russia, 2020, vol. 3, pp. 97-104. (In Russ.). DOI: $10.32651 / 203-97$

[19]F. Arias, C. Montoya, O. Velasquez, "Dynamics of the world avocado market", Revista Virtual Universidad Catolica del Norte, 2018, vol. 55, pp. 22-35. (In Span.). DOI: 10.35575/rvucn.n55a2

[20] N.Y. Kovalenko, G.Z. Ibiev, "Production and efficiency of fruit and berry products in the region", Economics of Agriculture of Russia, 2019, vol. 3, pp. 67-70. (In Russ.). DOI: 10.32651/193-67

[21]R.R. Mukhametzyanov, M.A.I. Fedorchuk, G.K. Dzhancharova, N.G. Platonovskiy, "Latin American countries and Russia in the international trade of the main tropical fruits", Economy of Agricultural and Processing Enterprises, 2021, vol. 10, pp. 48-59. (In Russ.). DOI: $10.31442 / 0235-2494-2021-0-10-48-59$
[22] W. Guevara, C. Hidalgo-Alcaza, J.L. Rojas, "Analysis of the Chilean Avocado (Palta) Agroindustry in the International Market", Chilean Journal of Agricultural \& Animal Sciences, 2021, vol. 37(1), pp. 54-64. DOI: 10.29393/CHJAAS37-6AAWG30006

[23] K.V. Sandoval, D.D. Avila, T.J.H. Gracia, "Study of the Mexican papaya market: an analysis of its competitiveness (2001-2015)", Suma de Negocios, 2017, vol. 8(18), pp. 131139. DOI: 10.1016/j.sumneg.2017.10.002

[24]D. Hernandez-Soto, F.J. Lopez-Chanez, A. Casique-Guerrero, "A Partial Equilibrium Analysis of Mexican Mango Exports to the United States", Agricultura Sociedad y Desarrollo, 2020, vol. 17(1), pp. 171-199.

[25]R.R. Mukhametzyanov, N.G. Platonovskiy, A.M. Khezhev, T.V. Ostapchuk, N.N. Ivantsova, "Foreign exchange earnings of the countries of the world from international trade in fruit and berry products", Economy of Agricultural and Processing Enterprises, 2021, vol. 8, pp. 45-56. (In Russ.). DOI: 10.31442/0235-2494-2021-0-8-45-56

[26]E.Y. Frolova, A.A. Nikonov, R.R. Mukhametzyanov, A.F. Korol'kov, A.S. Zaretskaya, "Contradictions to regulatory measures and their impact on global and national agricultural markets", in Proceedings of ISPC «Russia 2020 - a new reality: economy and society», Advances in Economics, Business and Management Research, 2021, vol. 164, pp. 276-280. DOI: 10.2991/aebmr.k.210222.054

[27] R.R. Mukhametzyanov, E.V. Britik, "Fruit and berries world production and international trade", Scientific Review: Theory and Practice, 2020, vol. 10(8-76), pp. 1445-1462. (In Russ.). DOI: $\quad 10.35679 / 2226-0226-2020-10-8-1445-$ 1464

[28] R.R. Mukhametzyanov, G.K. Dzhancharova, N.G. Platonovskiy, "Resources and use of fruit and berry products in the main countries of the EAEU", Economics of Agriculture of Russia, 2021, vol. 3, pp. 98-105. (In Russ.). DOI: $10.32651 / 213-98$

[29] E. Mansyah, A. Sutanto, "Tropical fruit research and development programs of Indonesian Tropical Fruits Research Institute (ITFRI)", IOP Conference Series: Earth and Environmental Science, 2020, vol. 583, p. 012013. DOI: 10.1088/1755-1315/583/1/012013 
[30] M.C. Garcia, P.Z. Arango, O.L.O. Lopez, D.D. Gomez, "Banana Exports as a Rural Development Strategy in Colombia”, 2019, vol. 38(68), pp. 113-148. (In Span.). DOI: 10.19053/01203053.v38.n68.2019.8383

[31] C.Y. Cheok, N.M. Adzahan, R.A. Rahman, N.H.Z. Abedin, N. Hussain, R. Sulaiman, G.H. Chong, "Current trends of tropical fruit waste utilization", Critical Reviews in Food Science and Nutrition, 2018, vol. 58(3), pp. 335361. DOI: 10.1080/10408398.2016.1176009

[32]V. Varma, D.P. Bebber, "Climate change impacts on banana yields around the world", Nature Climate Change, 2019, vol. 9(10), pp. 752-757. DOI: $10.1038 / \mathrm{s} 41558-019-0559-9$

[33]A.M.D. Ortiz, J.N.V. Torres, “Assessing the Impacts of Agriculture and Its Trade on Philippine Biodiversity”, Land, 2020, vol. 9(11), p. 403. DOI: 10.3390/land9110403

[34]R.R. Mukhametzyanov, G.K. Dzhancharova, N.G. Platonovskiy, "Russia in the international trade of major tropical fruits", Economics of Agriculture of Russia, 2021, vol. 12, pp. 78-85. (In Russ.). DOI: 10.32651/2112-78 